\title{
Sertifikat Laik Fungsi pada Bangunan Gedung di Kota Bandung Dalam Kaitannya dengan Izin Mendirikan Bangunan
}

\author{
Devi Elora* \\ Fakultas Hukum Universitas Langlangbuana Bandung \\ *Correspondence email: dvelora.unla@gmail.com
}

\begin{abstract}
Abstrak. Maraknya bangunan gedung di Kota Bandung merupakan simbol berkembangnya Kota Bandung itu sendiri, namun perkembangan suatu kota tentunya wajib mengacu pada aturan yang ada. Keberadaan bangunan gedung yang pada pemanfaatannya sering ditemukan tidak sesuai dengan IMB, dengan kata lain adanya ketidaksesuaian antara SLF dan IMB yang mana hal ini tentunya menimbulkan permasalahan mengenai pemanfaatan fungsi bangunan gedung yang tidak sesuai dengan izin mendirikan bangunan yang telah ada. Identifikasi masalah dalam penelitian tesis ini adalah bagaimana Pengaturan Hukum Mengenai SLF bangunan Gedung dalam keberadaan IMB serta bagaimanakah SLF bangunan gedung yang dalam pemanfaatannya tidak sesuai dengan IMB. Metode penelitian menggunakan metode yuridis normatif, yang dilakukan dengan menggunakan penelitian kepustakaan dan penelitian lapangan yang dilakukan pada lembaga-lembaga yang terkait dengan permasalahan sertifikat laik fungsi bangunan gedung di Kota Bandung dalam kaitannya dengan izin mendirikan bangunan. Kesimpulan yang didapatkan dalam penelitian ini adalah pengaturan Hukum Mengenai SLF bangunan Gedung dalam keberadaan IMB yang pada dasarnya keberadaan SLF berada atau didasarkan pada IMB. SLF merupakan suatu ketentuan pemanfaatan bangunan, sedangkan IMB merupakan legalitas keberadaan bangunan, permasalahan mengenai ketidaksesuaian antara IMB dan SLF dapat dikaji dari 3 subjek utama keberadaan SLF yaitu pemerintah, masyarakat dan aturan hukum, namun yang mendasar adalah tidak adanya aturan hukum mengenai petunjuk pelaksanaan khusus di Kota Bandung yang mengatur mengenai SLF, sehingga SLF di Kota Bandung belum dapat berjalan dengan baik. SLF bangunan gedung yang dalam pemanfaatannya tidak sesuai dengan IMB mengandung konsekuensi bahwa SLF yang seharusnya sesuai dengan IMB harus disesuaikan pemanfaatannya dengan ketentuan yang ada dalam IMB, keberadaan SLF ini mengandung arti bahwa pemanfaatan yang tertera dalam SLF harus sesuai .dengan ketentuan yang ada dalam IMB.
\end{abstract}

Kata Kunci: Bangunan; IMB; Sertifikat

\begin{abstract}
The rise of buildings in the city of Bandung is a symbol of the development of the city of Bandung itself, but the development of a city must of course refer to the existing rules. The existence of buildings whose utilization is often found to be inconsistent with IMB, in other words, there is a mismatch between SLF and IMB which of course raises problems regarding the use of building functions that are not in accordance with existing building permits. Identification of the problem in this thesis research is how the legal arrangements regarding SLF for buildings are in the presence of an IMB and how is the SLF for buildings that are not used in accordance with the IMB. The research method uses the normative juridical method, which is carried out using library research and field research conducted at institutions related to the issue of building function worthiness certificates in the city of Bandung in relation to building permits. The conclusion obtained in this study is the legal arrangement regarding SLF for buildings in the presence of an IMB which is basically the existence of an SLF located or based on an IMB. $S L F$ is a provision for the use of buildings, while IMB is the legality of the existence of buildings, problems regarding the incompatibility between IMB and SLF can be studied from 3 main subjects of the existence of SLF namely government, society and the rule of law, but what is fundamental is the absence of legal rules regarding specific implementation instructions in The City of Bandung regulates SLF, so that SLF in Bandung City has not been able to run well. SLF of buildings whose utilization is not in accordance with the IMB has the consequence that the use of the SLF that should be in accordance with the IMB must be adjusted to the provisions contained in the IMB.
\end{abstract}

Keywords: Building; IMB; Certificate

\section{PENDAHULUAN}

Pemerintah dalam hal ini ikut serta mengatur dan mengawasi pembangunan bangunan gedung melalui suatu aturan hukum yang dapat mengatur agar bangunan gedung dapat dibangun secara benar. Untuk menjamin kepastian dan ketertiban hukum dalam penyelenggaraan bangunan gedung, setiap bangunan gedung harus memiliki persyaratan administratif dan teknis bangunan gedung, serta harus diselenggarakan secara tertib. Undang-Undang Nomor 28 Tahun 2002 mengatur fungsi bangunan gedung, persyaratan bangunan gedung, penyelenggaraan bangunan gedung, termasuk hak dan kewajiban pemilik dan pengguna bangunan gedung pada setiap tahap penyelenggaraan bangunan gedung, ketentuan tentang peran masyarakat dan pembinaan oleh pemerintah, sanksi, ketentuan peralihan dan ketentuan pemerintah.

Pembangunan yang dilakukan demi kemajuan Negara Indonesia merupakan pembangunan yang diIakukan secara menyeluruh serta menyentuh segenap aspek hidup masyarakat dalam arti tidak hanya menitikberatkan pada satu bidang tertentu saja. 
Pembangunan pada bidang ekonomi merupakan penggerak utama membangunan, namun pembangunan ekonomi ini harus disertai upaya saling memperkuat, terkait, serta terpadu dengan pembangunan bidang lainnya. ${ }^{1}$

Terhadap bangunan gedung yang dibangun tersebut perlu diperhatikan mengenai perizinan pembangunannya yaitu dengan dibuatnya Izin Mendirikan Bangunan. Izin Mendirikan Bangunan yang selanjutnya akan disingkat IMB adalah perizinan yang diberikan oleh pemerintah daerah kepada pemohon untuk membangun baru, rehabilitasi/renovasi, dan atau memugar dalam rangka melestarikan bangunan sesuai dengan persyaratan administratif dan persyaratan teknis yang berlaku.

IMB sendiri adalah izin yang diberikan untuk melakukan kegiatan membangun yang dapat diterbitkan apabila rencana bangunan dinilai telah sesuai dengan ketentuan yang meliputi aspek pertanahan, aspek perencanaan, aspek kesehatan, aspek kenyamanan dan aspek lingkungan. IMB memiliki dasar hukum yang harus dipatuhi sehingga mutlak harus dimiliki setiap orang atau pihak yang berniat mendirikan bangunan. Dalam memperoleh IMB, Pemerintah daerah kota harus terlebih dahulu mengetahui dan memeriksa fungsi bangunan, apakah bangunan yang ingin dibangun berada pada area yang diijinkan, apakah memenuhi syarat ketentuan yang berlaku untuk bangunan di area itu, seperti dalam hal ketinggian bangunan maksimal dan fungsi bangunan, sehingga diharapkan pada masa penggunaannya, keberadaan bangunan tersebut tidak mengganggu lingkungan di sekitarnya.

Pada dasarnya keberadaan IMB bertujuan untuk menjaga keserasian antara bangunan dan lingkungannya. Sebuah bangunan dalam perencanaan konstruksinya harus memenuhi beberapa persyaratan khusus sesuai dengan peraturan pelaksanaan bangunan gedung. Hal ini diatur sebagai standar keselamatan bagi para penghuni bangunan maupun penduduk sekitarnya.

Telah diketahui pada pemaparan di atas bahwasannya SLF bukanlah suatu perizinan yang berdiri sendiri, namun keberadaannya mengikuti terbitnya IMB, namun yang menjadi permasalahan adalah pemanfaatan yang pada dasarnya melekat pada SLF tidak sesuai dengan yang telah ditentukan pada IMB, hal ini tentu saja secara sekilas menimbulkan keanehan, namun apabila dikaji dari akbita yang ditimbulkan baik akibat sosial maupun yuridis maka dapat diketahui bahwa ada ketimpangan pelaksanaan yang menyebabkan disorientasi keberadaan IMB dan SLF.

1 Hernawati Ras, Dani Durahman Aspek Hukum dalam Penyelenggaraan Bisnis Perhotelan, Jurnal Ilmiah Universitas Batanghari Jambi, 20(3), Oktober 2020, hlm. 1033

\section{Tinjauan Pustaka}

Dasar tujuan negara bahwa negara Indonesia sebagai negara hukum modern disamping bertugas memberikan perlindungan yang berkewajiban turut serta meningkatkan kesejahteraan masyarakat dalam semua sektor kehidupan. ${ }^{2}$ Untuk mencapai tujuan bangsa Indonesia yang telah ditetapkan dalam pembukaan Undang-Undang 1945 (selanjutnya disebut UUD 1945) yaitu mewujudkan suatu keadilan sosial bagi seluruh rakyat Indonesia.

Perkembangan pertumbuhan penduduk di suatu negara pada akhirnya menuntut pemerintah dalam mengatur dan menyediakan berbagai sarana sesuai dengan kebutuhan yang berlaku. Undang-Undang Dasar 1945 sebagai landasan konstitusional mewajibkan agar sumber daya alam dipergunakan untuk sebesar-besarnya bagi kemakmuran rakyat. Kemakmuran rakyat tersebut harus dapat dinikmati, baik oleh generasi sekarang maupun generasi yang akan datang.

\section{Pasal 33 ayat (3) Undang-Undang Dasar 1945 berbunyi: \\ "Bumi, air dan kekayaan yang terkandung di dalamnya dengan sebaik-baiknya untuk sebesar- besar kemakmuran rakyat."}

Hal ini menyatakan bahwa seluruh wilayah di Indonesia pada tingkatan tertinggi dikuasai negara sebagai organisasi kekuasaan seluruh rakyat, dan peruntukannya dipergunakan untuk mencapai tujuan kemakmuran rakyat. Pengertian menguasai negara tersebut merupakan kewenangan yang dimiliki oleh pemerintah terhadap air, ruang angkasa serta kekayaan alam yang terkandung di dalamnya. Pengertian dikuasai bukanlah berarti dimiliki tetapi kepada negara sebagai organisasi kekuasaan diberikan beberapa kewenangan. ${ }^{3}$

Peraturan diciptakan untuk ketertiban dan kesejahteraan masyarakat bukan untuk mengakibatkan rakyat sengsara, oleh karenanya peraturan itu harus menciptakan rasa keadilan, karena hukum yang jauh dari rasa keadilan hanya akan menciptakan anarkisme di masyarakat. Peraturan disusun dan disahkan untuk menciptakan ketentraman dan kerukunan hidup dalam masyarakat.

Asas-asas dalam bangunan gedung adalah:

1. Asas kemanfaatan, dipergunakan sebagai landasan agar bangunan gedung dapat diselenggarakan dan diwujudkan sesuai fungsi yang ditetapkan, serta sebagai wadah kegiatan manusia yang memenuhi nilai-nilai kemanusiaan yang berkeadilan, termasuk aspek kepatutan dan kepantasan.

2 Sjachran Basah, Perlindungan Hukum Terhadap Sikap Tindakan Administrasi Negara, Alumni, Bandung, 1992, hlm.3.

3 A.P. Parlindungan, Komentar atas Undang-Undang Pokok Agraria, Mandar Maju, Bandung, 1998, hlm. 47. 
2. Asas keselamatan, dipergunakan sebagai landasan agar bangunan gedung memenuhi persyaratan bangunan gedung, yaitu persyaratan keandalan teknis untuk menjamin keselamatan pemilik dan pengguna bangunan gedung, serta masyarakat dan lingkungan di sekitarnya, disamping persyaratan yang bersifat administratif.

3. Asas keseimbangan, dipergunakan sebagai landasan agar keberadaan bangunan gedung berkelanjutan tidak mengganggu keseimbangan ekosistem dan lingkungan di sekitar bangunan gedung.

4. Asas Keserasian bangunan gedung dengan lingkungannya, dipergunakan sebagai landasan agar penyelenggaraan bangunan gedung dapat mewujudkan keserasian dan keselarasan bangunan gedung lingkungan di sekitarnya.

Berdasarkan Pasal 1 butir 6 Peraturan Pemerintah Nomor 36 Tahun 2005 Tentang Peraturan Pelaksanaan Undang-Undang Nomor 28 Tahun 2002 Tentang Bangunan Gedung, IMB gedung adalah perizinan yang diberikan oleh Pemerintah Kabupaten/Kota kepada pemilik bangunan gedung untuk membangun baru, mengubah, memperluas, mengurangi, dan/atau merawat bangunan gedung sesuai dengan persyaratan administratif dan persyaratan teknis yang berlaku.

IMB gedung diberikan oleh pemerintah daerah, kecuali bangunan gedung fungsi khusus oleh pemerintah pusat, melalui proses permohonan IMB gedung. Proses permohonan IMB gedung harus mengikuti prinsipprinsip pelayanan prima dan murah/terjangkau. Permohonan IMB gedung adalah permohonan yang dilakukan pemilik bangunan gedung kepada pemerintah daerah untuk mendapatkan IMB gedung. ${ }^{4}$

Pengertian SLF Bangunan Gedung berdasarkan Pasal 1 angka 1 Peraturan Menteri Pekerjaan Umum Nomor : 25/Prt/M/2007 Tentang Pedoman Sertifikat Laik Fungsi Bangunan Gedung Maupun menurut Pasal 1 angka 45 Peraturan Daerah Kota Bandung Nomor 05 Tahun 2010 Tentang Bangunan Gedung adalah :

\section{"Sertifikat Laik Fungsi Bangunan Gedung adalah sertifikat yang diterbitkan oleh pemerintah daerah kecuali untuk bangunan gedung fungsi khusus oleh Pemerintah untuk menyatakan kelaikan fungsi suatu bangunan gedung baik secara administratif maupun teknis, sebelum pemanfaatannya."}

Suatu langkah diciptakan oleh pemerintah dalam menertibkan bangunan yang dibangun, yaitu berupa sebuah pedoman yang tertuang dalam sebuah peraturan Menteri Pekerjaan Umum Nomor: 25/Prt/M/2007 Tentang Pedoman Sertifikat Laik Fungsi Bangunan

4 Pasal 1 butir 7 PP Nomor 36 Tahun 2005 Tentang Peraturan Pelaksanaan Undang-Undang Nomor 28 Tahun 2002 Tentang Bangunan Gedung
Gedung. Pedoman ini dimaksudkan untuk menjadi acuan bagi pemerintah daerah, khususnya instansi teknis pembina penyelenggaraan bangunan gedung dalam menetapkan kebijakan operasional SLF bangunan gedung 5 .

Bangunan gedung itu sendiri menurut angka 4 Bagian Kesatu Ketentuan Umum adalah wujud fisik hasil pekerjaan konstruksi yang menyatu dengan tempat kedudukannya, sebagian atau seluruhnya berada di atas dan atau di dalam tanah atau di air yang berfungsi sebagai tempat manusia melakukan kegiatannya, baik untuk hunian atau tempat tinggal, kegiatan keagamaan, kegiatan usaha, kegiatan sosial budaya maupun kegiatan khusus.

Pelayanan adalah proses menyangkut segala usaha yang dilakukan oleh seseorang atau sekelompok orang dalam rangka mencapai tujuan ${ }^{6}$. Pelayanan hakekatnya adalah serangkaian kegiatan, karena itu merupakan suatu proses. Sebagai proses, pelayanaan berlangsung secara rutin dan berkesinambungan, meliputi seluruh kehidupan orang dalam masyarakat.

Pengendalian setiap kegiatan atau perilaku orang atau badan yang bersifat preventif adalah Izin yang secara gramatikal adalah pernyataan mengabulkan atau persetujuan membolehkan. Menurut Prajudi Atmosudirdjo Izin atau vergunning adalah dispensasi dari suatu larangan. ${ }^{7}$

Menurut pendapat Ateng Syafrudin dalam Ridwan $\mathrm{HR}$, izin bertujuan dan berarti menghilangkan halangan, hal yang dilarang menjadi boleh. Sementara itu menurut Sjahran Basah, izin adalah perbuatan hukum administrasi negara bersegi satu yang mengaplikasikan peraturan dalam hal konkreto berdasarkan persyaratan dan prosedur sebagaimana ditetapkan oleh ketentuan peraturan perundang-undangan ${ }^{8}$.

Pelaksanaan pelayanaan dapat diukur, oleh karena itu dapat ditetapkan standar baik dalam waktu yang diperlukan maupun hasilnya.

Pengertian tersebut mempunyai definisi yang sama persis dengan Peraturan Daerah Kota Bandung Nomor 05 Tahun 2010 Tentang Bangunan Gedung, hal ini tentunya untuk menjalankan prasarat yang tertuang dalam Pasal 7 Ayat (1) dan Pasal 8 Ayat (1) Peraturan Menteri Pekerjaan Umum Nomor : 25/Prt/M/2007 Tentang Pedoman Sertifikat Laik Fungsi Bangunan Gedung, Pasal 7 menyatakan :

${ }^{5}$ Pasal 2 Ayat (1) Peraturan Menteri Pekerjaan Umum Nomor : 25/Prt/M/2007 Tentang Pedoman Sertifikat Laik Fungsi Bangunan Gedung

${ }^{6}$ Moenir, Manajemen Pelayanan Umum Di Indonesia, Rineka Cipta, Jakarta, 2001, hlm 27

${ }^{7}$ Prajudi Atmosudirdjo dalam Philipus M. Hadjon, Pengantar Hukum Administrasi Indonesia, Gajah Mada University Press, Yogyakarta, 1999, hlm. 143

${ }^{8}$ Ridwan HR, Hukum Administrasi Negara, UII Press, Cetakan Kedua, Yogyakarta, 2003, hlm. 152 
"Dalam melaksanakan pembinaan penyelenggaraan bangunan gedung, Pemerintah melakukan peningkatan kemampuan aparat pemerintah propinsi, pemerintah kabupaten/kota maupun masyarakat dalam memenuhi ketentuan teknis..."

Pasal 8 Ayat (1) menyatakan:

"Pembinaan pelaksanaan pedoman ini dilakukan oleh Pemerintah dalam rangka meningkatkan kemampuan dan kemandirian pemerintah daerah dan masyarakat dalam penyelenggaraan bangunan gedung"

Pedoman mengenai SLF Gedung bertujuan untuk mewujudkan bangunan gedung yang selalu andal dan memenuhi persyaratan administratif dan persyaratan teknis bangunan gedung sesuai dengan fungsinya, guna mewujudkan bangunan gedung yang fungsional, sesuai dengan tata bangunan yang serasi dan selaras dengan lingkungannya, yang diselenggarakan secara tertib untuk menjamin keandalan teknis bangunan gedung, serta terwujudnya kepastian hukum dalam penyelenggaraan bangunan gedung 9 .

\section{METODE}

Penelitian ini menggunakan metode yuridis normatif, yaitu penelitian kepustakaan terhadap data sekunder di bidang hukum perijinan terkait SLF bangunan Gedung dalam keberadaan IMB, yang terdiri dari bahan-bahan hukum primer dan bahan-bahan hukum sekunder. Teknik pengumpulan data yang digunakan yaitu, studi kepustakaan yang terdiri dari pencarian konsepsi-konsepsi, teori-terori, yang berhubungan dengan permasalahan perbankan berupa peraturan perundang-undangan dibidang perijinan terkait SLF bangunan Gedung dalam keberadaan IMB. Spesifikasi penelitian yang digunakan bersifat deskriptif analitis dalam rangka mengkaji bahan-bahan yang bersumber dari kepustakaan dan peraturan perundang-undangan. Metode analisis data yang digunakan adalah normatif kualitatif untuk menentukan isi atau makna aturan hukum yang dijadikan rujukan dalam menyelesaikan permasalahan hukum perijinan terkait SLF bangunan Gedung dalam keberadaan IMB yang dikaji.

\section{HASIL DAN PEMBAHASAN \\ Pengaturan Hukum Mengenai SLF bangunan Gedung dalam keberadaan IMB}

Berdasarkan Pasal 10 Ayat (2) Peraturan Daerah Kota Bandung Nomor 05 Tahun 2010 Tentang Bangunan Gedung, terdapat prasyarat administrasi dalam mendirikan bangunan gedung, yaitu bukti hak atas

${ }^{9}$ Pasal 2 Ayat (2) Peraturan Menteri Pekerjaan Umum Nomor : 25/Prt/M/2007 Tentang Pedoman Sertifikat Laik Fungsi Bangunan Gedung. tanah, dan/atau izin pemanfaatan dari pemegang hak atas tanah; dan IMB. Berdasarkan Pasal 9 Ayat (1) Peraturan Daerah Kota Bandung Nomor 12 Tahun 2011 Tentang Penyelenggaraan, Retribusi Izin Mendirikan Bangunan Dan Retribusi Penggantian Biaya Cetak Peta Setiap pembangunan dan pemanfaatan gedung harus memenuhi persyaratan teknis bangunan gedung meliputi persyaratan tata bangunan dan persyaratan keandalan bangunan gedung. ${ }^{10}$

Permasalahan SLF ataupun IMB yang pada dasarnya merupakan permasalahan mengenai perizinan terkait erat dengan pelayanan dari pemerintah kepada masyarakat selaku ubjek hukum yang memerlukan izin dari pemerintah tersebut. Pelayanan yang diberikan oleh pemerintah kepada masyarakat seringkali disebut dengan pelayanan publik. Pelayanan publik dalam konteks ini dibatasi dalam pengertian pelayanan administratif, yaitu IMB, yang merupakan kewajiban warga masyarakat untuk memperoleh perizinan dari birokrasi negara.

Akuntabilitas, efektifitas maupun efisiensi pelaksanaan perizinan dalam penerbitan SLF menurut pendapat penulis sangat jauh dari yang diharapkan, aturan dan mekanisme yang ada hanya dijadikan suatu simbolisasi keberadaan saja, namun dalam pelaksanaannya dapat dikatakan minim.

Indikator-indikator tersebut menurut analisis yang dilakukan oleh penulis sangat jauh dari yang diharapkan, apabila kajiannya adalah keberadaan SLF, namun tidak dipungkiri pula, suatu sistem dapat berjalan bukan hanya pelaksana saja yang dijadikan objek kajian, namun aturan yang menaungi pelaksanaan dari suatu sistem tersebut merupakan hal yang penting juga. Sebagaimana diketahui pula, keberadaan SLF melekat pada keberadaan IMB, dengan kata lain IMB merupakan dasar penerbitan SLF atau SLF penerbitannya pasti mendasarkan pada keberadaan IMB. Fungsi dasar IMB adalah sebagai legalitas diadakannya atau dibangunnya suatu bangunan.

Secara teknis data yang melekat pada keberadaan IMB ini dijadikan dasar pula dalam penerbitan SLF, namun permasalahan terjadi ketika ketentuan mengenai IMB dihubungkan dengan SLF yang pada dasarnya keberadaan SLF berada atau didasarkan pada IMB, SLF merupakan suatu ketentuan pemanfaatan bangunan, sedangkan IMB merupakan legalitas keberadaan bangunan, tidak sejalan atau tidak sesuai antara data peruntukan yang terdapat dalam IMB dengan SLF. Mengkaji pengendalian penyelenggaraan bangunan gedung yang dilakukan dengan mendasarkan pada Penerbitan IMB serta penerbitan SLF bangunan gedung, perpanjangan SLF bangunan gedung. Mendasar pada hal tersebut maka pada dasarnya pasti kesesuaian antara IMB dan SLF harus tercipta.

${ }^{10}$ Pasal 15 Peraturan Daerah Kota Bandung Nomor 05 Tahun 2010 Tentang Bangunan Gedung 
Keberadaan SLF dilaksanakan hanya sebatas pemenuhan izin semata, karena pada kenyataannya adalah peruntukan yang ada dalam SLF sangat berbeda dengan pelaksanaan yang dilaksanakan oleh gedung yang bersangkutan, hal ini menimbulkan akibat dari sisi keberadaan SLF itu sendiri tentunya tidak menutup kemungkinan juga keberadaan gedung yang menyalahgunakan isi SLF tersebut menimbulkan dampak negatif bagi lingkungan sekitar.

\section{Konkritisasi Peran Pemkot Bandung dalam Menyikapi Bangunan Gedung}

TABG ini dapat meminta klarifikasi dan penjelasan dari Satuan Kerja Perangkat Daerah (SKPD) di lingkungan Pemerintah Kota Bandung berkenaan dengan proses pemberian IMB yang dikoordinasikan melalui Sekertariat Tim, yang selanjutnya menyampaikan laporan kegiatan secara berkala kepada Walikota Bandung. TABG juga dapat memberikan pertimbangan teknis dalam proses pengambilan keputusan yang berkenaan dengan persetujuan dokumen rencana teknis bangunan gedung untuk kepentingan umum dan bangunan tertentu untuk pemberian IMB, juga memfasilitasi partisipasi masyarakat dalam penyelesaian permasalahan yang berkenaan dengan teknis bangunan gedung. ${ }^{11}$

Dinas Tata Ruang Cipta Karya (Distarcip) mengungkapkan sepanjang 2014 pihaknya sudah menyegel sekitar 150 bangunan yang tidak memiliki izin mendirikan bangunan $(\mathrm{IMB})^{12}$. Berdasarkan hasil wawancara penulis dengan Kepala Seksi Peraturan Bangunan Distarcip Kota Bandung Henri Herawan mengatakan pihaknya sudah mensegel cukup banyak bangunan dengan berbagai jenis fungsi seperti bangunan tinggal, bangunan tinggi untuk perkantoran dan juga bangunan untuk kebutuhan toko ritel. Hal tersebut diarahkan untuk memperbaiki izin. Terlebih dari itu untuk melakukan pembongkaran, kami tidak memiliki hak untuk ranah tersebut.

Langkah untuk mengatasi hal tersebut, Distarcip menyebar kordinasi pada beberapa wilayah Kota Bandung seperti di Ujung Berung, Tegal Lega, Gede Bage dan daerah lainnya untuk melakukan tugas dan fungsi mobilisasi setiap harinya ${ }^{13}$. Baru-baru ini, Pemkot Bandung juga telah menyegel basement parkir mall Paris

\section{${ }^{11}$ Ibid}

12 wawancara penulis dengan Kepala Seksi Peraturan Bangunan Distarcip Kota Bandung Henri Herawan pada tanggal 15 Desember 2014

13 wawancara penulis dengan Kepala Seksi Peraturan Bangunan Distarcip Kota Bandung Henri Herawan pada tanggal 15 Desember 2014
Van Java karena dinilai menyalahi aturan atau tidak sesuai dengan izin mendirikan bangunan (IMB) ${ }^{14}$

Fungsi pemerintah daerah sebagai penerbit keberadaan SLF yang melekat atas keberadaan suatu gedung mempunyai tanggungjawab besar atas penyalahgunaan fungsi SLF. Tidak dipungkiri banyak kejadian penyalahgunaan tersebut diakibatkan karena keberadaan pemerintah tidak peka terhadap pemanfaatan gedung yang ada. Hal ini mengidentifikasikan bahwa SLF yang pada dasarnya merupakan penyeimbang antara aturan yang ada dengan pelaksanaan fungsi gedung tidak difungsikan secara optimal, sehingga mengasumsikan bahwa SLF hanya sebatas izin prosedural semata, karena izin sesungguhnya ada di IMB.

Mendasar pada ketentuan Pasal 7 Ayat (1) Peraturan Menteri Pekerjaan Umum Nomor: 5/Prt/M/2007 Tentang Pedoman Sertifikat Laik Fungsi Bangunan Gedung yang menyatakan bahwa dalam melaksanakan pembinaan penyelenggaraan bangunan gedung, pemerintah melakukan peningkatan kemampuan aparat pemerintah propinsi, pemerintah kabupaten/kota maupun masyarakat dalam memenuhi ketentuan teknis. Maka menurut pengamatan penulis secara praktik SLF ini hanya sebagai dispensasi saja mengingat keberadaannya jauh dari aturan yang ada sehingga wajar apabila pemanfaatannya sering menyalahi ketentuan yang ada dalam SLF itu sendiri. Pemerintah daerah selaku penerbit SLF mempunyai tanggungjawab penuh dalam meluruskan kinerja SLF ini, karena peran pemerintah sebagai penerbit SLF ini lah permasalahan atau ketiadaan masalah dapat diciptakan disamping tidak memungkiri adanya niatan tidak baik dari kepemilikan gedung yang bersangkutan.

\section{SIMPULAN}

1. Pengaturan Hukum Mengenai SLF bangunan Gedung dalam keberadaan IMB adalah pada dasarnya keberadaan SLF berada atau didasarkan pada IMB, SLF merupakan suatu ketentuan pemanfaatan bangunan, sedangkan IMB merupakan legalitas keberadaan bangunan, permasalahan mengenai ketidaksesuaian antara IMB dan SLF dapat dikaji dari 3 subjek utama keberadaan SLF yaitu Pemerintah, Masyarakat dan aturan hukum, namun mendasar tidak adanya aturan hukum yang khusus mengatur mengenai SLF maka aturan hukum dipandang sebagai hal utama SLF tidak berjalan baik

2. SLF bangunan gedung yang dalam pemanfaatannya tidak sesuai dengan IMB mengandung konsekuensi bahwa SLF yang seharusnya sesuai dengan IMB harus disesuaikan pemanfaatannya dengan ketentuan yang ada dalam IMB, keberadaan SLF ini mengandung arti bahwa pemanfaatan yang tertera

14 wawancara penulis dengan Kepala Seksi Peraturan Bangunan Distarcip Kota Bandung Henri Herawan pada tanggal 15 Desember 2014 
dalam SLF harus sesuai .dengan ketentuan yang ada dalam IMB

\section{Saran}

1. Pemerintah daerah Kota Bandung harus sesegera mungkin membuat suatu aturan yang mengatur mengenai SLF guna menciptakan iklim pembangunan gedung yang baik serta kondusif di Kota Bandung

2. Pemerintah daerah selaku penerbit SLF ataupun IMB harus lebih teliti dalam menegakan hukum mengenai penerbitan IMB dan SLF, sehingga dengan data yang ada pada pemerintah daerah sinkronisasi isi antara IMB dan SLF dapat tercipta.

\section{DAFTAR PUSTAKA}

\section{Buku}

Moenir, Manajemen Pelayanan Umum Di Indonesia, Rineka Cipta, Jakarta, 2001,

Parlindungan, A.P. Komentar atas Undang-Undang Pokok Agraria, Mandar Maju, Bandung, 1998

Prajudi Atmosudirdjo dalam Philipus M. Hadjon, Pengantar Hukum Administrasi Indonesia, Gajah Mada University Press, Yogyakarta, 1999

Ridwan HR, Hukum Administrasi Negara, UII Press, Cetakan Kedua, Yogyakarta, 2003

Sjachran Basah, Perlindungan Hukum Terhadap Sikap Tindakan Administrasi Negara, Alumni, Bandung, 1992

\section{Peraturan Perundang-undangan}

Undang-Undang Nomor 5 Tahun 1960 tentang Peraturan Dasar Pokok-Pokok Agraria

Undang-Undang Nomor 28 Tahun 2002 tentang Bangunan Gedung.

Peraturan Pemerintah Nomor 36 Tahun 2005 Tentang Peraturan Pelaksanaan Undang-Undang Nomor 28 Tahun 2002 Tentang Bangunan Gedung

Pemerintah Pengganti Undang-Undang Republik Indonesia Nomor 2 Tahun 2014 Tentang Perubahan Atas Undang-Undang Nomor 23 Tahun 2014 Tentang Pemerintahan Daerah

Peraturan Menteri Pekerjaan Umum Nomor : 25/Prt/M/2007 Tentang Pedoman Sertifikat Laik Fungsi Bangunan Gedung

Peraturan Menteri Dalam Negeri Republik Indonesia Nomor 32 Tahun 2010 Tentang Pedoman Pemberian Izin Mendirikan Bangunan.

Peraturan Daerah Nomor 05 Tahun 2010 Tentang Bangunan Gedung

Peraturan Daerah Kota Bandung Nomor 12 Tahun 2011 Tentang Penyelenggaraan, Retribusi Izin Mendirikan Bangunan Dan Retribusi Penggantian Biaya Cetak Peta

\section{Sumber Lain}

Annonimous, Antisipasi Pelanggaran Pendirian Gedung Pemkot Bandung Bentuk TABG, diunduh melalui http://www.bedanews.com/antisipasi-pelanggaranpendirian-gedung-pemkot-bandung-bentuk-tabg pada tanggal 16 Desember 2014

Hernawati Ras, Dani Durahman Aspek Hukum dalam Penyelenggaraan Bisnis Perhotelan, Jurnal Ilmiah Universitas Batanghari Jambi, 20(3), Oktober 2020

wawancara penulis dengan Kepala Seksi Peraturan Bangunan Distarcip Kota Bandung Henri Herawan pada tanggal 15 Desember 2014 tanggal akses 20 November 2020 